\title{
Terorisma tiesiskā regulējuma problēmas
}

\author{
Dr. iur. Valdis Voins \\ Rīgas Stradiña universitāte, Juridiskā fakultāte, Latvija \\ valdis.voins@rsu.lv
}

\section{Kopsavilkums}

Terorisma draudi pēdējos gados ir pieauguši un kḷuvuši daudzpusīgāki, tie ir viens no visnopietnākajiem universālo vērtību - cilvēka cienas, brīvības, līdztiesības un solidaritātes, cilvēktiesību un pamatbrīiību - pārkāpumiem un viens no visnopietnākajiem uzbrukumiem demokrātijas un tiesiskuma principiem. Teroristiskās vardarbības akti ir noziegumi pret sabiedrisko drošîbu un mieru. Saukt pie atbildỉbas par tiem var saskaņā ar vispārējām krimināltiesiskām normām par slepkavību, sprādzienu organizāciju un citiem vardarbīgiem noziegumiem bez nepieciešamības pierādìt speciālo teroristisko nodomu - tieši iebaidīt iedzīvotājus vai ietekmēt valdību veikt vai neveikt noteiktas darbības. Daudzas personas, kuru izdarìto noziedzīgo nodarïjumu pazīmes liecina par vēlmi ietekmēt valdību vai iebaidìt iedzīvotājus, sekmīgi notiesātas, nepiemērojot speciālos antiteroristiskos likumus. Speciālās normas tiek pieṇemtas, lai dotu iespēju saukt pie atbildības visu ar teroristisko darbïbu saistìto personu loku: organizatorus, vadītājus, vervētājus un atbalstītājus.

Laika gaitā katrā pasaules valstī ir izveidojusies sava krimināltiesību un kriminālprocesuālo tiesību sistēma. Nozīmīgākie krimināltiesību attīstību ietekmējošie faktori ir valsts geogrāfiskais stāvoklis, vēsture un sabiedrības attīstība, valstu nacionālās īpatnības un specifiskās iezīmes, noziedzības struktūra un tās jaunās izpausmes. Krimināltiesību attīstības virzienus ietekmē starptautisko un reǵionālo organizāciju izveide un darbība, kā arī politisko procesu attīstības tendences pasaulē. Ir svarīgi izveidot pienācīgus instrumentus, lai aizsargātu Eiropas Savienības (ES) pilsoṇus un visus ES iedzīvotājus un novērstu šādus pārkāpumus efektīvā un samērīgā veidā, kas ir pietiekams, lai risinātu apdraudējumu, ar ko saskaras ES, vienlaikus saglabājot sabiedrības modeli, kurā valda plurālisms, nediskriminācija, tolerance, taisnīgums, solidaritāte un līdztiesība.

Atslēgvārdi: krimināltiesības, vardarbība, terorisms. 


\section{levads}

Terorisma definēšanas problēma nav jauna, un pirmie mēginājumi rast vairākumam pieṇemamu terorisma definīciju sākās ar starptautiskās sadarbības attīstību cinnā ar noziedzību un krimināltiesību jomā. Krimināltiesību unifikācijas ideju nopietni sāka izskatīt Starptautiskās krimināltiesību asociācijas ${ }^{1}$ (International Association of Penal Law, IAPL) 1926. gada kongresā Briselē (Beḷgijāa). Krimināltiesību unifikācijas apspriešanai kongresā nodibināja kriminālistu konferenci. Pirmā konference par krimināltiesību unifikācijas jautājumiem notika 1927. gadā Varšavā (Polijā). Pavisam notika sešas konferences: 1928. gadā Romā (Itālijā), 1930. gadā Briselē, 1931. gadā Parīzē (Francijā), 1933. gadā Madridē (Spānijā), 1935. gadā Kopenhāgenā (Dānijā).

\section{ANO regulējums}

Pamatprasības terorisma atzīšanai par kriminālnoziegumu ietvertas ANO konvencijās, protokolos un rezolūcijās. Pēc universālo dokumentu par pretdarbību terorismam ratifikācijas valstīm nepieciešams uzsākt tajos ietverto normu un prasību iekḷaušanu nacionālajā likumdošanā. ANO dokumenta "Starptautiskie instrumenti cīñā ar starptautisko terorismu un tā novēršanu” priekšvārdā bijušais ANO generālsekretārs Kofi Annans pieaugošos terorisma draudus starptautiskajai sabiedrībai raksturoja šādi:

“Terorisms dod triecienu tieši Apvienoto Nāciju Organizācijas pamatvērtībām. Tas rada globālus draudus demokrātijai, likuma varas principam, cilvēktiesībām un vispārējai stabilitātei. Globalizācijas apstākḷos mums nepieciešams panākt reālu starptautisku sadarbību cīṇā ar terorismu visās tā formās un izpausmēs" [2].

Universālie starptautiskie dokumenti cīṇā ar terorismu nosaka dalībvalstīm obligāto regulējumu. Ja šie obligātie nosacījumi uzskatāmi par tiesību avotu, tad katrai dalībvalstij pašai jāizlemj, kādi formulējumi un apjomi ir adekvāti iekḷaušanai nacionālajā likumdošanā, lai saglabātu logiisku sakarību ar citiem noziedzīgiem nodarījumiem, par kuriem paredzēta atbildība nacionālajās krimināltiesībās. Apvienoto Nāciju Organizācijas Drošỉbas padome 2001. gada 28. septembrī pieṇemma Rezolūciju 1373 (2001), ar kuru noteica vispusīgas stratēgijas cīṇā pret terorismu un jo īpaši cīṇā pret terorisma finansēšanu.

Rezolūcijas 1373(2001) obligātās prasības dalïbvalstīm:

(a) ierobežot un novērst terora aktu finansēšanu;

(b) noteikt par kriminālsodāmu tīšu vai netiešu līdzekḷ nodrošināšanu vai iekasēšanu, ko veic valstspiederīgie vai ja darbības notiek to teritorijās ar nolūku, ka līdzekḷi tiks izmantoti, lai veiktu terora aktus;

1 Starptautiskā krimināltiesību asociācija tika nodibināta 1924. gada 14. martā. Tā var tikt uzskatīta par vienu no vecākajām zinātniskajām asociācijām pasaulē. Reizi piecos gados notiek organizācijas kongress. 
(c) nekavējoties iesaldēt to personu līdzekḷus un citus finanšu aktīvus vai saimnieciskos resursus, kuras izdara vai mēǵina izdarìt terora aktus, piedalās vai veicina terora aktu izdarī̌sanu;

(d) aizliegt saviem valstspiederīgajiem vai jebkurām personām un organizācijām to teritorijās tieši vai netieši darīt pieejamus jebkādus līdzekḷus, finanšu aktīvus vai saimnieciskos resursus, vai finanšu vai citus saistìtus pakalpojumus tādu personu labā, kuras izdara, veicina vai mēǵina izdarīt terora aktu [2].

Apvienoto Nāciju Organizācijas (ANO) Drošîbas padome savā Rezolūcijā 2178(2014) izteica bažas par pieaugošo apdraudējumu, ko rada ārvalstu kaujinieki teroristi, un visām ANO dalībvalstīm pieprasīja nodrošināt, lai nodarījumi, kas saistīti ar šo parādību, ir sodāmi, pamatojoties uz valstu tiesību aktiem [1]. Saskaṇā ar Rezolūcijas 6. punktu ANO dalïbvalstīm ir pienākums nodrošināt, ka to valstu tiesību akti paredz, ka nopietni noziedzīgi nodarījumi tiek izmeklēti un sodīti veidā, kas atspoguḷo nodarījuma smagumu, un šie nodarïjumi ir šādi:

a) cel̦ošana vai mēginājums cel̦ot uz trešo valsti nolūkā atbalstìt terora aktu veikšanu vai sniegt apmācību vai to saṇemt;

b) šādas celıš̌anas finansēšana;

c) šãdas cel̦ošanas organizēšana vai sekmēšana.

Personas, kas ir ceḷojušas uz konfliktu zonām, turpinās radìt paaugstinātu apdraudējumu visām ES dalībvalstīm. Kaujinieki, kas atgriežas, papildus jauniem kontaktiem varētu būt ieguvuši kaujas un operāciju pieredzi, kā rezultātā tie varētu būt spējīgi veikt daudzskaitlīgus uzbrukumus ar lielākām sekām. Eirojust savā 2014. gada ziņojumā sadaḷā “Terorisms" [8] norāda, ka viena no devin,ām personām, kura atgriezusies no konflikta zonām, vēlāk iesaistās teroristiskā darbībā.

Starptautiskā radikalizācijas un politiskās vardarbības izpētes centra direktors Pēters Neimanis ${ }^{2}$, 2017. gadā uzstājoties konferencē Londonā ar ziṇojumu "Old and New Terrorism: How will Jihadism Evolve?” [11], publiskoja viña rīcībā esošos datus par ārvalstnieku dalību konfliktā Sīrijā un Irākā ISIL pusē. 2013. gadā Sīrijā karoja 600 Rietumeiropas valstu pilsoṇu. Visvairāk kaujnieku bija no Lielbritānijas (160), Nīderlandes (100) un Vācijas (40).

2015. gada sākumā teroristu pusē cīnijās jau 20000 ārvalstnieku, savukārt 2017. gadā skaits pieauga līdz 30 000, t. sk. 4000 no Rietumeiropas (Francijas, Lielbritānijas, Vācijas). Piecsimt Beḷgijas pilsoṇu piedalījās militārā konfliktā Sīrijā - tas ir proporcionāli lielākais skaits uz iedzìvotāju skaitu valstī.

2 Pēters Neimanis (Peter Neumann), arī Londonas Karaḷa koledžas Militāro studiju katedras drošības pētijumu profesors. 


\section{Eiropas Padomes ${ }^{3}$ regulējums}

2015. gada 22. maijā Rīgā tika pieņemts Papildu protokols Eiropas Padomes Konvencijai par terorisma novēršanu, ar ko ievieš atsevišķus ANO Drošības padomes Rezolūcijā 2178(2014) paredzētos krimināltiesību noteikumus.

Papildu protokols paredz kriminālatbildības noteikšanu par šādiem nodarījumiem: dalība apvienībā vai grupā terorisma nolūkos (2. pants), terorisma apmācības saṇemšana (3. pants), ceḷošana vai cel̦ošanas mēǵinājumi terorisma nolūkos (4. pants), finansējuma sniegšana vai vākšana šādai cel̦ošanai (5. pants) un šādas celıš̌anas organizēšana un veicināšana (6. pants). Tajā arī paredzēts, ka puses pastiprina savlaicīgu informācijas apmaiṇu savā starpā (7. pants).

\section{Eiropas Savienības un Latvijas Republikas regulējums}

Krimināltiesisko un kriminālprocesuālo regulējumu būtiski ietekmē Eiropas Savienības tiesību attīstība, kas ir vērsta uz tiesību harmonizāciju un pārrobežu sadarbības veicināšanu. Par kriminālpolitikas izveidošanas sākumu nākamajai Eiropas Savienībai pieņemts uzskatīt īpašas koordinācijas institūcijas izveidošanu 1975. gadā. Runa ir par t. s. TREVI grupu, kas sastāvēja no valstu iekšlietu ministriem. Grupas nosaukums ir abreviatūra no franču valodas vārdiem Terrorisme, Radicalisme, Extrémisme et Violence Internationale (terorisms, radikālisms, ekstrēmisms un starptautiskā vardarbība) [9].

Māstrihtas līgums ${ }^{4}$ nostiprināja jau esošās saites starp policijas un tiesu iestāžu sadarbību krimināllietās. Ar Lisabonas līguma ${ }^{5}$ stāšanos spēkā atseviškłas ar trešo pīlāru saistītās jomas - tieslietas un iekšlietas - ir pārgājušas no dalībvalstu kompetences Kopienas kompetencē: vīzu un bēgḷu politika, iebraukšanas un uzturēšanās tiesības trešo valstu pilsoniem, tiesu sadarbība civillietās.

2019. gadā par teroristiska rakstura noziegumiem 12 ES dalībvalstīs tika nolasīti spriedumi 520 personām (sk. tabulu). Lìdzīgi kā pēdējos gados ES dalībvalstīs, lielākā dal̦a (n = 362) notiesāto personu bija saistītas ar džihāda terorismu. Lielākais skaits notiesājošo spriedumu ES par džihāda terorismu 2019. gadā pasludināti Beḷ́gijas un Francijas tiesās - attiecīgi $\mathrm{n}=89$ un $\mathrm{n}=87$, savukārt Nìderlandē $-\mathrm{n}=49$ un Vācijā $-\mathrm{n}=42$. Vidējais cietumsoda ilgums par teroristiskiem nodarījumiem ES 2019. gadā bija seši gadi par vienu gadu mazāk nekā 2015. gadā. Zemākais cietumsods, ko ES dalībvalstīs tiesa

${ }^{3}$ Eiropas Padome (angl. Council of Europe) - 1949. gadā dibināta starpvalstu organizācija, kuras mērḳis ir veicināt ekonomisko un sociālo progresu. Eiropas Padomē ir 47 dalībvalstis (nav Baltkrievijas, Kosovas un Vatikāna).

4 Māstrihtas līgums tika parakstīts 1992. gada 7. februārī, stājās spēkā 1993. gada 1. novembrī. Ar Māstrihtas līgumu Eiropas Savienībai bija noteiktas pilnvaras, kas ir sadalītas trijās grupās un parasti tiek sauktas par pīlāriem.

${ }^{5}$ Lisabonas līgums tika parakstīts 2007. gada 13. decembrī. Tajā ir pilnvaru sadalījums attiecībā uz to, kas ir ES kompetencē, kas ir ES dalībvalstu pārzin̄ā, par ko kopīgi atbild ES un tās dalībvalstis. 
piesprieda 2019. gadā, bija viens mēnesis un augstākais - mūža ieslodzījums. Belı́gijas tiesa 2014. gada maijā ar mūža ieslodzījumu notiesāja vainīgo par uzbrukumu Ebreju muzejam Briselē. Dažos gadījumos personām, kas notiesātas par teroristiskiem nodarījumiem, tika atñemta ES dalïbvalsts pilsonība.

Tiesībaizsardzības iestādes ES saskārās ar vairākām praktiskām un juridiskām problēmām saistībā ar ar pierādījumu vākšanu un izmantošanu par ārvalstu kaujinieku izdarìtajiem noziegumiem:

- grūti iegūt pierādījumus no kaujaslaukiem Sīrijā un Irākā;

- problemātiski vākt un izmantot pierādijjumus, kas balstās uz internetu;

- bieži vien ir vajadzīga pārrobežu tiesiskā palīdzība, lai piekḷūtu pierādījumiem (jo notiek ārvalstu kaujinieku tranzìts caur citām valstīm, interneta pakalpojumu sniedzēji varētu atrasties ārvalstīs).

"Eurojust" savā pārskatā [7] norāda, ka reǵistrēti 10 notiesāšanas gadījumi uz aptuveni 3000 ES valstspiederīgo / pastāvīgo iedzīvotāju, kas saistīti ar ārvalstu kaujinieku darbību.

N̦emot vērā to, kā ir pieauguši terorisma draudi un juridiskās saistības pret ES un dalībvalstīm saskaṇā ar starptautiskajām tiesībām, teroristu nodarījumu, nodarỉjumu, kas saistīti ar teroristu grupu, un nodarïjumu, kas saistīti ar teroristu darbībām, definīcija būtu vēl vairāk jātuvina visās dalībvalstīs, lai tā vispusīgāk aptvertu rīcību, kas saistīta jo īpaši ar ārvalstu kaujiniekiem teroristiem un terorisma finansēšanu. Šāda veida rīcỉbai vajadzētu būt sodāmai arī tad, ja tā izdarīta, izmantojot internetu, tostarp sociālos plašsazin̦as līdzekḷus. Lai apkarotu pārrobežu terorismu, vajadzīga spēcīga un koordinēta atbildes rīcība un sadarbība dalībvalstīs un starp tām, kā arī ar un starp kompetentajām ES aǵentūrām un struktūrām, tostarp Eurojust un Eiropolu. Tāpēc būtu efektīvi jāizmanto pieejamie sadarbības instrumenti un resursi, piemēram, jāveido kopējas izmeklēšanas grupas un Eurojust atbalstītas koordinācijas sanāksmes. Terorisms ir globāla parādība, tādēl ir nepieciešama starptautiska atbilde, liekot ES un tās dalībvalstīm stiprināt sadarbību ar trešajām valstīm. Spēcīga un koordinēta atbildes rīcība un sadarbỉba ir vajadzīga arī, lai nodrošinātu un iegūtu elektroniskus pierādījumus.

2002. gada Padomes Pamatlēmumā 2002/475/TI4 bija noteikta kriminālatbildība par

- konkrētiem terora aktiem, jo īpaši par terora aktu veikšanu;

- dalïbu teroristu grupējuma darbībās;

- finansiālu atbalstu teroristiskām darbībām;

- publisku aicinājumu veikt terora aktu;

- teroristu vervēšanu un apmācību;

- teroristu nodarījumu atbalstīšanu un līdzdalību tajos;

- kūdǐšanu uz teroristu nodarījumu veikšanu;

- mēgininājumu tos veikt. 
Par teroristiska rakstura noziegumiem notiesāto personu skaits Eiropas Savienībā no 2016. līdz 2019. gadam [6]

\begin{tabular}{|l|r|r|r|r|}
\hline \multirow{2}{*}{ Valsts } & \multicolumn{4}{c|}{ Gads } \\
\cline { 2 - 5 } & 2019 & 2018 & 2017 & 2016 \\
\hline Austrija & 40 & 36 & 18 & 26 \\
\hline Beḷǵija & 91 & 80 & 85 & 136 \\
\hline Dānija & 4 & 6 & 4 & 8 \\
\hline Igaunija & - & - & 2 & 2 \\
\hline Somija & - & 1 & 2 & 4 \\
\hline Francija & 105 & 141 & 122 & 66 \\
\hline Vācija & 53 & 57 & 34 & 30 \\
\hline Griek̦ija & 45 & 33 & 19 & 3 \\
\hline Ungārija & 6 & 3 & - & 2 \\
\hline Itālija & 17 & 15 & 23 & 11 \\
\hline Lietuva & - & 10 & 2 & 1 \\
\hline Nīderlande & 56 & 37 & 46 & 42 \\
\hline Portugāle & 1 & - & 1 & 1 \\
\hline Slovēnija & - & 1 & - & 1 \\
\hline Spānija & 97 & 120 & 71 & 154 \\
\hline Zviedrija & 5 & 1 & 3 & 4 \\
\hline Apvienotā Karaliste & - & 115 & 125 & 89 \\
\hline Bulgārija & - & 1 & - & - \\
\hline Čehija & - & 7 & 8 & - \\
\hline Polija & 520 & 664 & 569 & 580 \\
\hline Kopā ES & & & & - \\
\hline
\end{tabular}

Tomēr Pamatlēmumā 2002/475/TI netika skaidri prasīts noteikt kriminālatbildību par ceḷošanu uz trešajām valstīm terorisma nolūkā, ne arī par dalību apmācībā terorisma nolūkiem. Tika sagatavots priekšlikums jauna Pamatlēmuma pieñemšanai, kurš aizstātu Pamatlēmumu 2002/475/TI. Priekšlikuma mērḳis bija ieviest atjauninātus ES līmeņa tiesību aktus, ar ko nosaka minimālos noteikumus par teroristu nodarījumu, nodarījumu, kas saistīti ar teroristu grupām un teroristu darbībām, definēšanu un sodus šajā sakarā. Priekšlikuma juridiskais pamats ir Līguma par Eiropas Savienības darbību 83. panta 1. punkts. Saskañā ar šo pantu Eiropas Parlaments un Padome, pieñemot direktīvas saskaṇā ar parasto likumdošanas procedūru, var paredzēt noteikumu minimumu noziedzīgu nodarījumu un sankciju definēšanai. 2017. gada 7. martā Eiropas Savienības Vispārējo lietu padomē pieñēma Eiropas Parlamenta un Padomes Direktīvu (ES) 2017/541 par terorisma apkarošanu un ar ko aizstāj Padomes Pamatlēmumu 2002/475/TI par terorisma apkarošanu [4]. Direktīvā ir paredzēti minimālie noteikumi noziedzīgu nodarỉjumu 
un sankciju definēšanai attiecībā uz teroristu nodarījumiem, nodarījumiem saistībā ar teroristu grupu un nodarījumiem, kas saistìti ar teroristu darbībām, kā arī aizsardzības pasākumi, atbalsts un palīdzība terorismā cietušajiem.

Terorisms kā noziegums (noziedzīgs nodarījums) ir daḷa no plašākas krimināli sodāmu parādību sadal̦as, tāpēc ir būtiski noteikt kopējo un atšķirīgo starp atseviškiem - varbūt arī līdzīgiem - noziedzīgiem nodarījumiem. Teroristiskais akts un citi noziedzīgie nodarījumi ar terorisma pazīmēm jāatšḳir no politiskajām un pasūtījuma slepkavībām, kā arī citiem vardarbīgiem noziegumiem. Pie kriminālatbildības saskaṇā ar Krimināllikumu Latvijā ir saucama un sodāma tikai persona, kura ir vainīga noziedzīga nodarījuma izdarǐšanā, tas ir, kura ar nodomu (tî̌si) vai neuzmanības dēḷ izdarïjusi Krimināllikumā paredzētu nodarījumu, kam ir visas noziedzīga nodarījuma sastāva pazīmes. P. Mincs ${ }^{6}$ 1934. gadā publicētajā grāmatā noziedzīgu nodarỉjumu definēja kā "pretlikumīgu, vainojamu, sodāmu cilvēku uzvešanos, kas atbilst vienam no tipiskiem sastāviem" [9].

Izskatìt jēdziena "terorisms" attīstību krimināltiesībās Latvijas teritorijā jāsāk no laika, kad Latvija bija Krievijas Impērijas sastāvā. Krievijas cars Nikolajs II 1903. gada 22. martā apstiprināja Sodu likumus (Уголовное уложение, 1903). Vācu militārā vara Pirmā pasaules kara laikā, pakāpeniski okupējot Latvijas teritoriju, Sodu likumus pilnā apjomā, pielāgojot okupācijas režīma vajadzībām, ieviesa spēkā vispirms Kurzemē, bet vēlāk arī Vidzemē. Nākamais politiskais režìms - Latvijas Tautas padome - 1918. gada 6. decembrī atstāja spēkā Latvijā okupācijas varas ieviestos 1903. gada Sodu likumus. Pēc padomju varas padzišanas Tautas padome ar 1919. gada 5. decembra likumu noteica, ka Latvijā ir spēkā visi Krievijas likumi, kas nav atcelti Latvijā. Latgalē Sodu likumus ieviesa ar 1920. gada 15. marta likumu.

1903. gada Sodu likumi ar Saeimas vēlāk izdarītajiem grozijumiem Latvijas teritorijā bija spēkā līdz 1933. gada 1. augustam, kad tos aizstāja Latvijas brīvvalsts pirmais krimināllikums - Sodu likums -, kurš tika izstrādāts uz 1903. gada Krievijas Sodu likumu bāzes, ņemot vērā Vācijas, Itālijas un citu valstu likumdošanas praksi un jaunākos sasniegumus krimināltiesību teorijā. No jauna bija izveidota 7. nodaḷa - Noziedzīgi nodarïjumi pret ārvalstīm -, kura noteica atbildību par noziedzīgiem nodarïjumiem pret ārvalstu vadītājiem, diplomātiskajiem pārstāvjiem, šo valstu īpašumu utt. Sodu likums bija spēkā līdz 1940. gada 25. novembrim, kad pēc Latvijas okupācijas un iekḷaušanas Padomju Savienības sastāvā okupācijas vara Latvijā ieviesa Krievijas Padomju Federatīvās Sociālistiskās Republikas (KPFSR) 1926. gada kriminālkodeksu.

KPFSR 1926. gada kriminālkodekss Latvijā bija spēkā līdz 1961. gada 31. martam, izṇemot vācu okupācijas laiku. 1961. gada 6. janvārī Latvijas Padomju Sociālistiskās Republikas Augstākā Padome apstiprināja Latvijas Padomju Sociālistiskās Republikas kriminālkodeksu.

6 Pauls Mincs (Šmuels Faivls Mincs, 1868-1941) - Latvijas jurists un politiḳis, darba ministrs (1920-1921), Latvijas Universitātes profesors, Latvijas Sodu likuma izstrādāšanas komisijas priekšsēdētājs. 
Kodeksā ir paredzēta atbildỉba par teroristiskiem nodarïjumiem: 61. pants - "Terora akts", 62. pants - "Terora akts pret ārvalsts pārstāvi", 63. pants - "Diversija".

Pēc valstiskās neatkarības atjaunošanas Latvijas Republikas Augstākā Padome ar 1991. gada 29. augusta lēmumu "Par Latvijas PSR likumdošanas aktu piemērošanu Latvijas Republikas teritorijā" nolēma uzskatīt Latvijas Padomju Sociālistiskās Republikas kriminālkodeksu par Latvijas Kriminālkodeksu līdz jauna Latvijas Republikas Kriminālkodeksa pieñemšanai.

Pēc valstiskās neatkarības atjaunošanas pirmā nozīmīgā krimināltiesību reforma tika pabeigta 1999. gadā, kad spēkā stājās Krimināllikums, aizstājot līdz tam esošo Latvijas Kriminālkodeksu. 1991. gada 22. augustā Latvijas Republikas Augstākā Padome pieṇēma Latvijas Republikas likumu "Par grozijumiem un papildinājumiem Latvijas PSR kriminālkodeksā un Latvijas PSR kriminālprocesa kodeksā”.

Salīdzinot Latvijas PSR Kriminālkodeksa un Latvijas Kriminālkodeksa normas attiecībā uz noziedzīgo nodarījumu "terorisms", jāsecina, ka

1) Latvijas PSR Kriminālkodeksa 61. pants “Terora akts” Latvijas Kriminālkodeksā pārveidots par 61. pantu "Latvijas Republikas tautas deputāta, valdības locekḷa vai citas amatpersonas dzīvības vai veselïbas apdraudējums", kaut arī abi paredz atbildību par valsts amatpersonu dzīvības vai veselības apdraudējumu;

2) Latvijas PSR Kriminālkodeksa 62. pants "Terora akts pret ārvalsts pārstāvi" pārtapa par Latvijas Kriminālkodeksa 62. pantu "Ārvalsts pārstāvja dzīvības vai veselības apdraudējums". Abos pantos noteikta atbildība par uzbrukumu (noslepkavošanu) ārvalsts pārstāvim, apdraudot viṇa dzīvību vai veselību;

3) Latvijas PSR Kriminālkodeksa 63. pantu "Diversija" bez būtiskām izmaiṇām ieḳ̣āva Latvijas Kriminālkodeksā, kura 63. pantā "Diversija” saglabāti rīcības veidi un iespējamie diversijas uzbrukumu objekti;

4) piemērojot Latvijas PSR Kriminālkodeksa normas Latvijas Republikas teritorijā, no kriminālās likumdošanas izzuda jēdziens "terora akts".

1999. gada 1. aprīlī stājās spēkā Krimināllikums, ar kura pieṇemšanu būtiskas izmainas tika panāktas krimināltiesību vispārīgās daḷas noteikumos, kā arī tika pārskatīti Latvijas Kriminālkodeksā ietverto noziedzīgo nodarījumu sastāvi.

Krimināllikuma 88. pantā terorisms skaidrots kā

- spridzināšana;

- dedzināšana;

- cita tîša darbība, kas vērsta uz cilvēku iznīcināšanu, miesas bojājumu vai cita kaitējuma radīšanu cilvēka veselībai;

- uzñēmumu, celtṇu, naftas vai gāzes vadu, elektrolīniju, satiksmes ceḷu un līdzekḷu, telekomunikāciju tìklu, valsts nozīmes jonizējošā starojuma objektu vai citas mantas iznīcināšana vai bojāšana;

- kodolavārija, radiācijas avārija (no 15.06.2000.) [4], masveida saindēšana vai epidēmiju un epizootiju izplatīšana nolūkā kaitēt Latvijas Republikai vai tās iedzīvotājiem. 
Salïdzinot Latvijas Kriminālkodeksā definēto diversiju ar Krimināllikuma 88. panta 1. dal̦ā paredzēto terorismu, viegli saskatìt ārējo līdzību. Būtỉbā Krimināllikuma 88. panta 1. dạ̦ā ir paplašināts teroristisko rīcību uzskaitỉjums un virsraksts "diversija" ir aizstāts ar vārdu "terorisms". Tomēr mūsdienu izpratnē terorisms ir ne vien darbïba, kas apdraud nacionālās intereses, bet arī nodarījums, kas vērsts pret sabiedrisko drošību un mieru neatkarīgi no tā izdarīšanas vietas. 2006. gada 5. janvārī stājās spēkā Grozỉjumi Krimināllikumā, kuros izteikta 88. panta "Terorisms" jaunā redakcija, kurā terorisms nav tieši saistīts ar kaitējuma nodarīšanu Latvijas Republikai:

“(1) Par šādām darbībām, ja tās veiktas nolūkā iebiedēt iedzīvotājus vai piespiest valsti, tās institūcijas vai starptautiskas organizācijas izdarīt kādu darbību vai atturēties no tās, vai kaitēt valsts, tās iedzīvotāju vai starptautiskās organizācijas interesēm:

1) spridzināšana;

2) dedzināšana;

3) kodolieroču, ķīmisko, biologiisko, bakteriologisko, toksisko vai citu masveida iznīcināšanas ieroču ražošana;

4) personas nolaupī̌̌ana;

5) kīlnieku sagrābšana;

6) šaujamieroču, šaujamieroču munīcijas, lielas energijas ieroču, sprāgstvielu vai spridzināšanas ietaišu neatḷautu izgatavošana, remontēšana, iegādāšanās, glābšana, nēsāšana, pārvadāšana, pārsūtīšana, realizēšana, pielietošana;

7) gaisa, sauszemes vai ūdens transportlīdzekl̦a sagrābšana;

8) tīša darbība, kas vērsta uz cilvēku iznīcināšanu, miesas bojājumu vai cita kaitējuma nodarīšanu cilvēku veselībai;

9) uzṇēmumu, būvju, kontinentālajā šelfā nostiprinātu platformu, naftas vai gāzes vadu, elektrolīniju, satiksmes cel̦u vai lïdzekl̦u, elektronisko sakaru tīklu, valsts nozīmes jonizējošā starojuma objektu iznīcināšana vai bojāšana;

10) kodolavārija vai radiācijas avāriju izraisīšana;

11) masveida saindēšana;

12) epidēmiju, epizootiju izplatī̌sana;

13) draudi īstenot šīs dal̦as iepriekš minētajos punktos paredzētās darbības, ja ir pamats uzskatìt, ka šie draudi var tikt izpildìti.

(2) Par šā panta pirmajā daḷā paredzētajām darbībām, ja tās ir izdarītas personu grupā pēc iepriekšējās vienošanās (teroristu grupu).

(3) par teroristu grupas vadīšanu" [5].

Salīdzinot iepriekšējo un 2006. gada Krimināllikuma 88. panta redakciju, redzams, ka jaunajā redakcijā iekḷautas teroristiska rakstura papildu darbības, par kurām iestājas kriminālatbildỉba:

- visu veidu masveida iznīcināšanas ieroču izpēte, ražošana un izplatīšana;

- personu nolaupišana un ḳīnieku sagrābšana;

- šaujamieroču, munīcijas un sprāgstvielu iegādāšanās, izgatavošana, realizācija, izmantošana;

- transportlīdzekḷa sagrābšana.

Panta redakcijā izdarīts precizējums: jēdziens "telekomunikāciju tīkls" mainīts uz "elektronisko sakaru tīkli". Panta 2. un 3. dạ̣ā paredzēta atbildība par teroristisko 
darbību veikšanu grupā (teroristu grupā) pēc iepriekšējas vienošanās un par teroristu grupas vadīšanu. Nosakot atbildību par darbību noziedzịgā organizācijā (grupā) vai tās vadīšanu, jāṇem vērā, ka 2002. gada 23. maijā stājās spēkā Grozỉjumi Krimināllikumā, kuri papildināja Krimināllikumu ar 89. ${ }^{1}$ pantu "Noziedzīga organizācija":

“(1) Par tādas noziedzīgas organizācijas (apvienības) izveidošanu, kuru sastāvā ir vismaz piecas personas, nolūkā izdarīt sevišḳi smagus noziegumus pret cilvēci vai mieru, kara noziegumus, ìstenot genocīdu vai izdarìt sevišk și smagus noziegumus pret valsti, kā arī par iesaistîšanos šādā organizācijā vai tās sastāvā ietilpstošā organizētā grupā vai citā noziedzīgā formējumā.

(2) Par noziedzīgas organizācijas vadīšanu vai piedalīšanos šādas organizācijas izdarītajos šā panta pirmajā dạ̦ā paredzētajos noziegumos."

Krimināllikuma 88. pantā "Terorisms" un 88. ${ }^{1}$ pantā "Terorisma finansēšana” ir paredzēta atbildība par teroristiska rakstura darbībām grupā, teroristu grupas izveidošanu un vadišanu un terorisma finansēšanu, ko darïjusi personu grupa. Organizētas grupas jēdziens noformulēts Krimināllikuma 21. pantā "Organizēta grupa":

“(1) Organizēta grupa ir vairāk nekā divu personu izveidota apvienība, kura radīta nolūkā kopīgi izdarīt vienu vai vairākus noziegumus un kuras dalïbnieki saskaṇā ar iepriekšejju vienošanos sadalījuši pienākumus.

(2) Atbildība par nozieguma izdarīšanu organizētā grupā personai iestājas šajā likumā paredzētajos gadījumos par grupas izveidošanu un vadī̌̌anu, piedalī̌̌anos smaga vai seviški smaga nozieguma sagatavošanā vai nozieguma izdarǐšanā neatkarīgi no personas lomas kopīgi izdarītajā nodarījumā." [5]

Aktuālā Krimināllikuma 88. panta “Terorisms" redakcija ir spēkā no 2008. gada 12. janvāra:

“(1) Par spridzināšanu, dedzināšanu, kodolḳīmisko, ḳimisko, biologisko, bakteriologisko, toksisko vai citu masveida iznīcināšanas ieroču lietošanu, masveida saindēšanu, epidēmiju, epizootiju izplatīšanu, personas nolaupī̌sanu, ḳīlnieku sagrābšanu, gaisa, sauszemes vai ūdens transportlīdzekḷ sagrābšanu vai citādām darbībām, ja tās veiktas nolūkā iebiedēt iedzīvotājus vai piespiest valsti, tās institūcijas vai starptautiskas organizācijas izdarīt kādu darbību vai atturēties no tās, vai kaitēt valsts, tās iedzīvotāju vai starptautiskas organizācijas interesēm (terorisms).

(2) Par valsts teritorijā vai kontinentālajā šelfā izvietotu fizisku objektu, automatizēto datu apstrādes sistēmu, elektronisko tīklu, kā arī citu objektu, kuru mērḳis ir nodrošināt valsts drošību, iznīcināšanu vai bojāšanu, ja šādas darbības veiktas šā panta pirmajā daḷā paredzētajā nolūkā.

(3) Par šā panta pirmajā un otrajā daḷā paredzētajām darbībām, ja tās izdarītas personu grupā pēc iepriekšējās vienošanās (teroristu grupa).

(4) Par teroristu grupas izveidošanu un vadiš̌anu." [5]

Panta pirmās dal̦as dispozīcijā nav iekḷautas vairākas terorismu veidojošās darbības, kuras bija norādītas iepriekšējā redakcijā, - kodolieroču un citu masveida iznīcināšanas ieroču ražošana un izplatīšana. Tomēr tajā nav sašaurināta atbildība par terorismu, jo, kaut arī tajā nav terorismu veidojošo darbību izsmel̦oša uzskaitījuma, taču ir norādīts, ka par 
teroristiskām var tikt atzītas arī citādas darbības. Krimināllikuma 88. panta pirmā daḷa satur precizētu terorisma nolūka definīciju, kas ir saskaņota ar Padomes Pamatlēmuma 2002/475/TI (2002. gada 13. jūnijs) par terorisma apkarošanu 1. panta prasībām.

“Teroristiskais akts nav pašmērḳis, gandrīz vienmēr tas darbojas caur noteiktu sabiedriski politisko rezonansi, un, jo lielāka tā ir, jo plašāk izplatās informācija par to" [11].

Teroristus par šiem noziegumiem var sodīt, izmantojot Krimināllikumā paredzētās sankcijas: par slepkavību, sprādzienu organizēšanu, cilvēku nolaupīšanu un citām vardarbīgām darbībām, izslēdzot nepieciešamību speciāli pierādìt teroristisko nodomu. Atš̌kirībā no speciālajām normām vispārējās kriminālās jurisdikcijas nepilnība vai vājums kontekstā ar terorismu ilgstoši bija tas, ka vainīgo kriminālvajāšana var sākties, ja darbības, kuras izraisījušas tragiskas vai postošas sekas, ir jau notikušas vai noticis reāls mēǵinājums tās realizēt. Turklāt sodītas galvenokārt personas, kuras ir tieši piedalījušās vai veikušas nodarījumu. Tas apgrūtina saukšanu pie atbildības tos, kuri fiziski neatradās nozieguma izdarī̌sanas vai draudu izteikšanas vietā un tieši nav piedalijjušies vardarbības aktā. Teroristi neatkarīgi no viṇu ideolog̣ijas un politiskajiem uzstādījumiem savu mērḳi cenšas sasniegt, slepkavojot, nodarot miesas bojājumus, sagrābjot kịilniekus, iznīcinot ipašumu vai izsakot draudus veikt visas šìs darbỉbas.

2017. gada 7. martā Eiropas Savienības Vispārējo lietu padomē pieṇēma Eiropas Parlamenta un Padomes Direktīvu (ES) 2017/541 par terorisma apkarošanu un ar ko aizstāj Padomes Pamatlēmumu 2002/475/TI par terorisma apkarošanu. Direktīva paredz minimālos noteikumus noziedzīgu nodarījumu un sankciju definēšanai attiecībā uz teroristu nodarījumiem, nodarījumiem saistībā ar teroristu grupu, kā arī aizsardzības pasākumus, atbalstu un palīdzỉbu terorismā cietušajiem. Dalïbvalstīm bija nepieciešams transponēt to savos tiesību aktos. 2018. gada 26. aprīlī Saeima pieñēma Grozījumus Krimināllikumā, ar kuriem Krimināllikumu papildina ar IX ${ }^{1}$ nodaḷu "Noziegumi, kas saistīti ar terorismu", kurā tiek ietverti gan tādi noziedzīgi nodarījumi, kas jau bija Krimināllikumā, gan arī jauni noziedzịi nodarījumi, iekḷaujot likumā Papildu protokolā un Direktīvā paredzētās darbības.

Līdz ar Grozijumu pien̦emšanu noziedzīgie nodarỉjumi, kas saistīti ar terorismu, no nodaḷas "Noziegumi pret valsti" pārcelti uz jaunu nodaḷu "Noziegumi, kas saistīti ar terorismu" ar sešiem pantiem:

“79. ${ }^{1}$ pants. Terorisms.

79. ${ }^{2}$ pants. Terorisma finansēšana.

79. ${ }^{3}$ pants. Teroristu grupa.

79. ${ }^{4}$ pants. Personas vervēšana, apmācīšana un apmācī̌sanās terorismam.

79. ${ }^{5}$ pants. Celıšana terorisma nolūkā.

79. ${ }^{6}$ pants. Terorisma attaisnošana, aicinājums uz terorismu un terorisma draudi."

Nodạ̦ā "Noziegumi pret valsti" tika ietverti kaitīgi un prettiesiski nodarījumi, kas apdraud Latvijas valsts drošību un neatkarību, un galvenais grupas objekts tajā ir būtiski Latvijas valsts interešu aizskārumi. Terorismam var būt divējādas dabas: vienā 
gadījumā teroristu grupa vai individuāls terorists var cīnīties par noteiktas valsts dalias "atbrīvošanu" vai citādu ietekmēšanu, savukārt otrā gadījumā tā var būt politiska kustība, kuras darbības iziet ārpus valsts robežām, un tās mērḳis ir iedarboties uz visu pasaules sabiedrību kopumā. Šobrīd pasaulē terorismam nav valstu robežu un tā mērḳis ir vērsts ne tikai pret konkrētu valsti, bet arī pret visas pasaules sabiedrību kopumā. Lai aptvertu abus iespējamos apdraudējuma objektus, noziedzīgos nodarījumus, kas saistīti ar terorismu, bija nepieciešams ietvert atsevišķā nodaḷā, tādējādi skaidri norādot, ka persona, kas iesaistās terorisma nodarïjumos, var apdraudēt ne tikai konkrētas valsts intereses, bet arī starptautisko mieru un drošỉbu.

Nosauktie noziedzīgie nodarījumi ir kriminālsodāmi visās tiesību sistēmās neatkarīgi no tā, vai tajās ir speciālas normas par terorismu. Šãdu noziegumu sastāvu elementi ir pierādāmi arī tad, ja nav iespējams nodemonstrēt (pierādìt) tieši teroristiskajai darbībai raksturīgo gribu (nodomu) ar vardarbības aktu iebaidìt iedzìvotājus vai piespiest kaut ko izdarìt valdỉbu. Daudzas personas, kuras ir vainīgas vardarbīgos aktos pret mierīgajiem iedzīvotājiem (turklāt šo nodarījuma raksturs, konteksts un veicēju iepriekšējā darbība lauj saskatìt tiešu nodomu ar vardarbības palīdzību iebaidìt iedzìvotājus vai izdarìt spiedienu uz valdību) tika sekmīgi sauktas pie kriminālatbildības, neizmantojot speciālas pret teroristisko darbỉbu vērstas normas un nepierādot teroristisko nodomu. Neizmantojot speciālās normas, tika notiesāti vainīgie par nodarỉjumiem, kuri guva plašu rezonansi sabiedrībā: par sprādzienu 1983. gada jūnijā Orlī lidostā (Francijā) pie turku aviolīnijām, kuru organizēja armēṇu teroristiskais grupējums "ASALA", un japāņu sektas "Aum Shinrikyo"8 terorakts Tokijas metropolitēnā 1995. gadā, izsmidzinot zarīna gāzi (bojā gāja 12 cilvēki, un bija gandrīz seši tūkstoši cietušo).

\section{Secinājumi}

Valstis veido un attīsta savu krimināltiesību un kriminālprocesuālo tiesību sistēmu. Nozīmīgākie krimināltiesību attīstību ietekmējošie faktori: valsts ǵeogrāfiskais stāvoklis, vēsturiskā sabiedrības attīstība, valstu nacionālās īpatnības, noziedzības struktūra un tās jaunās izpausmes. Krimināltiesību attīstības virzienus ietekmē starptautisko un reg̣ionālo organizāciju izveide un darbība, politisko procesu attīstības tendences pasaulē.

Nepieciešams izveidot pienācīgus instrumentus, lai aizsargātu Eiropas Savienības (ES) iedzīvotājus, novērstu pārkāpumus efektīvā un samērīgā veidā, kas ir pietiekams, lai mazinātu apdraudējumu riskus, ar ko saskaras ES, vienlaikus saglabājot sabiedrības modeli, kurā valda plurālisms, nediskriminācija, tolerance, taisnīgums, solidaritāte un līdztiesība. Speciālās tiesību normas tiek pieṇemtas, lai dotu iespēju saukt pie atbildības

\footnotetext{
7 ASALA (no anglu val. Armenian Secret Army for the Liberation of Armenia) - Armēnijas slepenā armija Armēnijas atbrīvošanai.

8 "Aum Shinrikyo" (japāṇu val. - Augstākā patiesība). Sektas vadītājs - Shoko Asahara (Chizuo Matsumoto).
} 
visu ar teroristisko darbību saistìto personu loku: izpildītājus, organizatorus, vadītājus, vervētājus, atbalstītājus.

Saskaroties ar jauniem izaicinājumiem, ES bija nepieciešami saskaņotāki, visaptverošāki un pielāgotāki valstu krimināltiesību noteikumi, lai varētu efektīvi novērst ārvalstu kaujinieku teroristu uzbrukumus un izmeklēt ar tiem saistītos nodarījumus, kā arī atbilstoši reagêèt uz problēmjautājumiem, kas saistīti ar pārrobežu juridiskajiem un praktiskajiem aspektiem. 2017. gada 7. martā Eiropas Savienības Vispārējo lietu padomē pieñēma Eiropas Parlamenta un Padomes Direktīvu (ES) 2017/541 par terorisma apkarošanu, ar ko aizstāja Padomes Pamatlēmumu 2002/475/TI par terorisma apkarošanu. Direktīva paredz minimālos noteikumus noziedzīgu nodarījumu un sankciju definēšanai attiecībā uz teroristu nodarījumiem, nodarījumiem saistībā ar teroristu grupu, kā arī aizsardzības pasākumus, atbalstu un palīdzību terorismā cietušajiem.

Latvija ir pilnībā izpildījusi Eiropas Padomes 2005. gada Konvencijas "Par terorisma novēršanu" un Eiropas Parlamenta un Padomes Direktivas (ES) 2017/541 par terorisma apkarošanu ietvertās prasības, ka teroristiskie nodarījumi ir sodāmi saskaṇā ar nacionālo likumdošanu.

\section{Problems of Legal Regulation of Terrorism}

\section{Abstract}

Terrorist threat has grown and evolved in recent years. Acts of terrorism constitute one of the most serious violations of universal values: human dignity, freedom, equality and solidarity, human rights and fundamental freedoms, and they also represent one of the most serious attacks on the principles of democracy and the rule of law. Acts of terrorist violence are crimes against public security and peace.

They can be prosecuted in accordance with the general criminal law provisions on murder, organisation of explosions and other violent crimes, without the need to prove the special terrorist intent to intimidate the population directly or influence the government to take or not to take certain actions.

A large number of people whose criminal characteristics make it possible to see a desire to influence the government or to intimidate the population have been successfully convicted without applying special anti-terrorist laws. The special rules are adopted to enable the entire spectrum of persons involved in terrorist activity to be brought to justice: organisers, managers, recruiters, supporters.

Over time, each country in the world has developed its own criminal law and criminal justice system.

The most important factors affecting the development of criminal law include: geographical location, history and societal development of the country, national specificities and specific features of the country, structure of crime and its new manifestations. 
Developments in criminal law are influenced by the establishment and functioning of international and regional organisations and developments in political processes around the world.

It is important to have adequate tools in place to protect $\mathrm{EU}$ citizens and all people living in the EU and counter such violations in an effective and proportionate manner, which are adequate to meet up to the threats the EU is confronted with, while preserving a society in which pluralism, non-discrimination, tolerance, justice, solidarity and equality prevail.

Keywords: criminal law, violence, terrorism.

\section{Avoti un literatūra}

1. ANO Drošības padome. Rezolūcija 2178 (2014). Iegūts no: https://documents-dds-ny.un.org/ doc/UNDOC/GEN/N14/547/98/PDF/N1454798.pdf?OpenElement [sk. 12.03.2021.].

2. United Nations. Security Council. Resolution 1373 (2001). Iegūts no: https://undocs.org/en/S/ RES/1373(2001) [sk. 12.03.2021.].

3. United Nations. International Instruments Related to the Prevention and Suppression of International Terrorism. Iegūts no: https://www.unodc.org/documents/terrorism/ Publications/Int_Instruments_Prevention_and_Suppression_Int_Terrorism/Publication_-_ English_-_08-25503_text.pdf [sk. 10.10.2020.].

4. Eiropas Parlamenta un Padomes Direktiva (ES) 2017/541par terorisma apkarošanu un ar ko aizstāj Padomes Pamatlēmumu 2002/475/TI par terorisma apkarošanu. Iegūts no: https://eurlex.europa.eu/legal-content/LV/TXT/?uri=CELEX:32017L0541 [sk. 12.03.2021.].

5. Krimināllikums: Latvijas Republikas likums: pieṇemts 17.06.1998. un stājās spēkā: 01.04.1999. Latvijas Vēstnesis.199/200(1260/1261), 08.07.1998.

6. Europol. EU Terrorism situation and Trend report - 2019 (TE-SAT 2020). Iegūts no: https:// www.europol.europa.eu/activities-services/main-reports/european-union-terrorism-situationand-trend-report-te-sat-2020 [sk. 01.11.2020.].

7. Eurojust. Eurojust Annual Report 2019. Iegūts no: https://www.eurojust.europa.eu/eurojustannual-report-2019-0 [sk. 12.03.2021.].

8. Eurojust. 2014. gada pārskats. Iegūts no: https://www.eurojust.europa.eu/sites/default/files/ Publications/AnnualReport/Annual-Report-2014-LV.pdf [sk.12.03.2021.].

9. Mincs, P. 2005. Krimināltiesību kurss. Vispārējā daḷa. Ar U. Krastiṇa komentāriem. Rìga: Tiesu namu aǵentūra, 71. lpp.

10. Vilks, A. Eiropas Savienības kopējā krimināltiesiskā politika: ieskats vēsturē un attīstības perspektīvas. Rīgas Stradiña universitātes Zinātniskie raksti 2007. 21.

11. Neumann, P. Old and New Terrorism: How will Jihadism Evolve? Iegūts no: https://www.youtube. com/watch?v=bxQRL7tCEgo [sk. 10.10.2020.].

12. Boyar-Sazonovich, T. S. 1991. Mezhdunarodnyj terrorizm: politiko-pravovye aspekty. Kiev, Odessa: Lybid, 119-120. 